\title{
"Earnings management initiatives and selected characteristics of an entity: a case study of the Visegrad Four"
}

\begin{tabular}{|c|c|}
\hline \multirow{5}{*}{ AUTHORS } & Anna Siekelova (D https://orcid.org/0000-0001-6571-8476 \\
\hline & R https://publons.com/researcher/P-5595-2015 \\
\hline & \multirow{3}{*}{$\begin{array}{l}\text { Katarina Valaskova (D https://orcid.org/0000-0003-4223-7519 } \\
\text { R https://publons.com/researcher/1628011/katarina-valaskova/ } \\
\text { Veronika Machova }\end{array}$} \\
\hline & \\
\hline & \\
\hline ARTICLE INFO & $\begin{array}{l}\text { Anna Siekelova, Katarina Valaskova and Veronika Machova (2020). Earnings } \\
\text { management initiatives and selected characteristics of an entity: a case study of } \\
\text { the Visegrad Four. Problems and Perspectives in Management, 18(3), 28-41. } \\
\text { doi:10.21511/ppm.18(3).2020.03 }\end{array}$ \\
\hline DOI & http://dx.doi.org/10.21511/ppm.18(3).2020.03 \\
\hline RELEASED ON & Thursday, 06 August 2020 \\
\hline RECEIVED ON & Tuesday, 05 May 2020 \\
\hline ACCEPTED ON & Thursday, 16 July 2020 \\
\hline & $(\mathrm{cc}) \overline{E Y}$ \\
\hline LICENSE & $\begin{array}{l}\text { This work is licensed under a Creative Commons Attribution } 4.0 \text { International } \\
\text { License }\end{array}$ \\
\hline JOURNAL & "Problems and Perspectives in Management" \\
\hline ISSN PRINT & $1727-7051$ \\
\hline ISSN ONLINE & $1810-5467$ \\
\hline PUBLISHER & LLC “Consulting Publishing Company "Business Perspectives" \\
\hline FOUNDER & LLC "Consulting Publishing Company "Business Perspectives" \\
\hline & 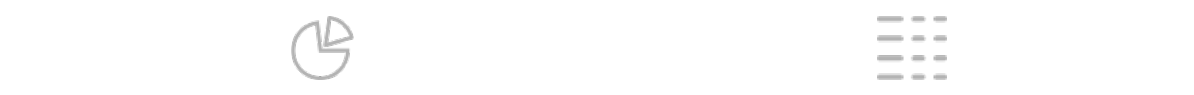 \\
\hline NUMBER OF REFERENCES & NUMBER OF FIGURES \\
\hline 29 & 6 \\
\hline
\end{tabular}

(C) The author(s) 2022. This publication is an open access article. 


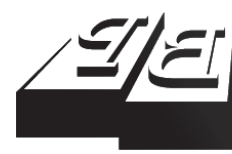

\section{BUSINESS PERSPECTIVES}

(O)

LLC "CPC "Business Perspectives" Hryhorii Skovoroda lane, 10, Sumy, 40022, Ukraine www.businessperspectives.org

Received on: $5^{\text {th }}$ of May, 2020 Accepted on: $16^{\text {th }}$ of July, 2020 Published on: $6^{\text {th }}$ of August, 2020

() Anna Siekelova, Katarina Valaskova, Veronika Machova, 2020

Anna Siekelova, Ph.D., Faculty of Operation and Economics of Transport and Communications, Department of Economics, University of Zilina, Slovak Republic. (Corresponding author)

Katarina Valaskova, Ph.D., Faculty of Operation and Economics of Transport and Communications, Department of Economics, University of Zilina, Slovak Republic.

Veronika Machova, MBA, Director of School of Expertness and Valuation, Institute of Technology and Business in Ceske Budejovice, Ceske Budejovice, Czech Republic.
Anna Siekelova (Slovak Republic), Katarina Valaskova (Slovak Republic), Veronika Machova (Czech Republic)

\section{EARNINGS MANAGEMENT INITIATIVES AND SELECTED CHARACTERISTICS OF AN ENTITY: A CASE STUDY OF THE VISEGRAD FOUR}

\begin{abstract}
This paper responds to the current issue of Earnings Management (hereafter EM) initiatives in the Visegrad Four. The aim is to identify EM practices and determine a statistically significant relationship between EM practices and firm size, country, or business sector. The paper contains a literature review, bibliometric analysis, and a description of the methods used in the practical part. Many publications containing the term "EM" in scientific databases, a keyword science map for "EM" publications, a science map of the most cited contributions dealing with EM, a science map of countries with the highest number of cited publications with the term "EM", and a science map of sources with the highest number of publications with the term "EM" are included. The analysis covers the period from 1900 to 2019. The study is focused on detecting the presence of EM initiatives in the Visegrad Four using the modified Jones model. Results confirmed the EM initiatives in the Czech Republic, Slovak Republic, Poland, and Hungary. Using the one-way ANOVA test, a statistically significant relationship was confirmed between EM practices and firm size, country, and business sector. The study uses a sample of 250 financial statements of entities from each Visegrad Four country for the year 2018. The sample is adjusted for outliers using the IQR method.
\end{abstract}

Keywords

JEL Classification earnings, earnings management, modified Jones model, total accruals, discretionary accruals

M41, M42, G14

\section{INTRODUCTION}

This paper deals with EM initiatives since at least the 1960s. Initial research was focused on earnings management and capital markets. Two types of hypotheses can be distinguished, namely the mechanistic hypothesis and the efficient market hypothesis. Unlike the mechanistic hypothesis, the effective market hypothesis assumes that investors deal with the impact of accounting choices on the profit amount. It can be assumed that stock prices are determined by public available information, including the accounting policy. Later studies were focused on the impact of earnings management on the non-capital market (Whittle, Gregova, Podhorska, \& Rowland, 2019; Khan \& Thu, 2019).

Mulford and Comiskey (2002) defined the following motives for Earnings Management practices:

- avoiding the risk of decline in stock prices if the earnings achieved are lower than expected;

- creating the best picture of profit to maximize the selling price of stocks if the company is considering an IPO; 
- keeping profit at the level needed to get the maximum possible premium;

- reducing profit volatility due to one-off items;

- also changes in management give rise to new management efforts to show lower earnings in the first periods after accession, in order to attribute such a situation as a result of old management decisions.

The interest in the EM issue is constantly growing. Recently published studies bring new results in this area. However, most studies are conducted abroad and thus do not reflect the economic conditions of the V4 countries. The aim of the current paper is to identify EM practices and to determine a statistically significant relationship between EM practices and firm size, country, or business sector. The study is carried out in the economic conditions of the Visegrad Four countries.

\section{LITERATURE REVIEW}

Since the 1960s, a large number of studies have been created that examine EM from different perspectives. Many definitions of EM can be found. McKee (2005) defines EM as the purposeful and legal management of decision-making and reporting in order to achieve stable and predictable economic results. Davidson et al. (2005) define EM as the process of intentional steps within the limits of Generally Accepted Accounting Principles in order to achieve the required level of reported profit. According to Sankar and Subramanam (2001), EM is the use of flexibility in the selection of accounting methods that influence managers' decisions about future cash flows. Schipper (1989) refers to EM as the "disclosure management." Ronen and Yaari (2008) distinguish three types of EM, namely white earnings management, gray earnings management, and black earnings management. It can also be referred to as beneficial indicates the long-term value, neutral - reveals true short-term performance, and harmful conceals the long-term or the short-term value.

The composition of profit from two components, cash flow and accrual, leads companies to two forms of EM, namely real earnings management and accrual-based earnings management. Entities are able to manage profits through appropriate operational decisions that have an impact on cash flow from operating activities. Such EM is referred to as "real earnings management" (Rowchowdhury, 2006). The second option is to adjust the accrual in order to achieve the required level of profit. Such EM is referred to as "accrual-based earnings management" or "accounting earnings management". The possibility for such profit management is provided by the accounting standards, principles, or laws themselves (Kljucnikov, Belas, \& Smrcka, 2016; Udell, Stehel, Kliestik, Kliestikova, \& Durana, 2019; Suprianto, Rahmawati, Setiawan, \& Aryani, 2019).

Earnings Management is a current topic and is studied by several experts. Recent studies may include those by Barber and Hollie (2020), Premti and Smith (2020) dealing with the connection between EM and IPO, Assenso-Okofo, Ali, and Ahmed (2020) studying the effects of the global financial crisis on the relationship between CEO compensation and EM, Salehi, Shiri, and Hossini (2020) focusing on the relationship between managerial ability, EM and internal control quality on audit fees in Iran, Asghar et al. (2020) dealing with discretionary EM, or Kim et al. (2020) whose study is connected with real earnings management and the cost of debt capital. Kliestik, Kovacova, Valaskova, Michalkova, Cug, Cugova, Siekelova, Podhorska, etc. can be included among domestic authors dealing with the EM issue (Durana, Kral, Stehel, Lazaroiu, \& Sroka, 2019; Kovacova, Kliestik, Valaskova, Durana, \& Juhaszova, 2019, Podhorska, Gajanova, Kliestikova, \& Popescu, 2019; Vrbka, Nica, \& Podhorska, 2019, Durica, Podhorska, \& Durana, 2019; Sadaf, Olah, Popp, \& Mate, 2019; Hudakova, Masar, Luskova, \& Patak, 2018).

Table 1 represents the most frequently used methods for calculating EM chronologically arranged. 
Table 1. The most frequently used calculation methods of EM

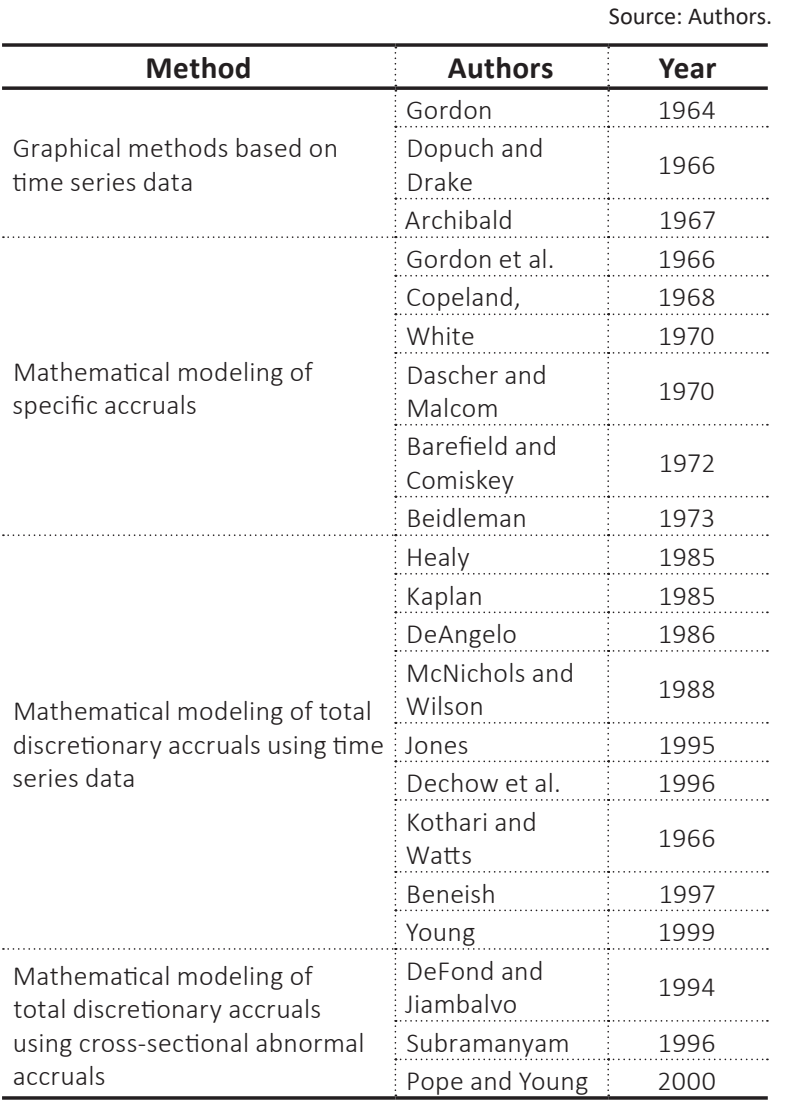

\subsection{Bibliometric analysis}

The use of statistical methods to analyze articles, publications, or books is known as bibliometrics. Scientometrics, also defined as the sub-field of bibliometrics, deals with the analysis of scientific publications. Bibliometric analysis is widely used in various fields of science. Most often, bibliometrics, or scientometrics, is associated with the evaluation of science at various levels. Historical development in selected science fields, as well as hidden relationships between issues, authors, or disciplines, can be defined based on the results of bibliometric analysis. Bibliometric methods are also used to identify the most current topics of scientific research or the level of their obsolescence.

The following bibliometric analysis presents the topicality of the Earnings Management issue. The bibliometric analysis is divided into two parts based on the selected period (1900-2000; 20002019). Table 2 shows the characteristics of conducted bibliometric analysis.
Table 2. Characteristics of the conducted bibliometric analysis

\begin{tabular}{|c|c|}
\hline $\begin{array}{l}\text { Analyzed } \\
\text { databases }\end{array}$ & $\begin{array}{l}\text { Web of Science } \\
\text { SciVerse Scopus } \\
\text { Social Science Research Network (SSRN) }\end{array}$ \\
\hline Years analyzed & $1900-2019 *$ \\
\hline \multirow{2}{*}{ Methods used } & Descriptive statistics \\
\hline & Maps of science \\
\hline \multirow{6}{*}{$\begin{array}{l}\text { Bibliometric } \\
\text { analysis } \\
\text { subjects }\end{array}$} & $\begin{array}{l}\text { Number of publications containing the term } \\
\text { "Earnings Management" in scientific databases }\end{array}$ \\
\hline & $\begin{array}{l}\text { Keyword science map for "Earnings } \\
\text { Management" publications (1900-2000) }\end{array}$ \\
\hline & $\begin{array}{l}\text { Keyword science map for «Earnings } \\
\text { Management» publications (2001-2019) }\end{array}$ \\
\hline & $\begin{array}{l}\text { Science map of the most cited authors dealing } \\
\text { with the problem of "Earnings Management" } \\
(1900-2019)\end{array}$ \\
\hline & $\begin{array}{l}\text { Science map of countries with the highest } \\
\text { number of cited publications with the term } \\
\text { "Earnings Management" (1900-2019) }\end{array}$ \\
\hline & $\begin{array}{l}\text { Science map of sources with the highest } \\
\text { number of publications with the term "Earnings } \\
\text { Management" (1900-2019) }\end{array}$ \\
\hline
\end{tabular}

Note: * 2020 is not included because the year has not finished yet.

Figures 1 and 2 show the results of bibliometric analysis using descriptive statistics. Figure 1 shows the number of publications with the term "Earnings Management" in Social Science Research Network.

Social Science Research Network's eLibrary provides 930,539 research papers from 480,575 researchers in more than 50 disciplines. 1,495 records containing the term "Earnings Management" were posted from 1995 to 2020. 24 records have been posted in 2020 (till May 12, 2020) and nine records do not have the date of posting. The oldest record, Dividend-Based Earnings Management: Empirical Evidence from Finland, was posted on June 12, 1995.

Another database, Web of Science, has 1,875 publications containing the term "Earnings Management" published from 1900-2020 (till May 12, 2020). 44 publications have been published in 2020. The first was published in 1969. Figure 2 shows the development of the number of publications containing the term “Earnings Management" in 1900-2019.

Figure 2 proves the topicality of the EM issue; it also shows that the interest in this topic in the scientific community has increased mainly during the last 19 
Source: Authors.

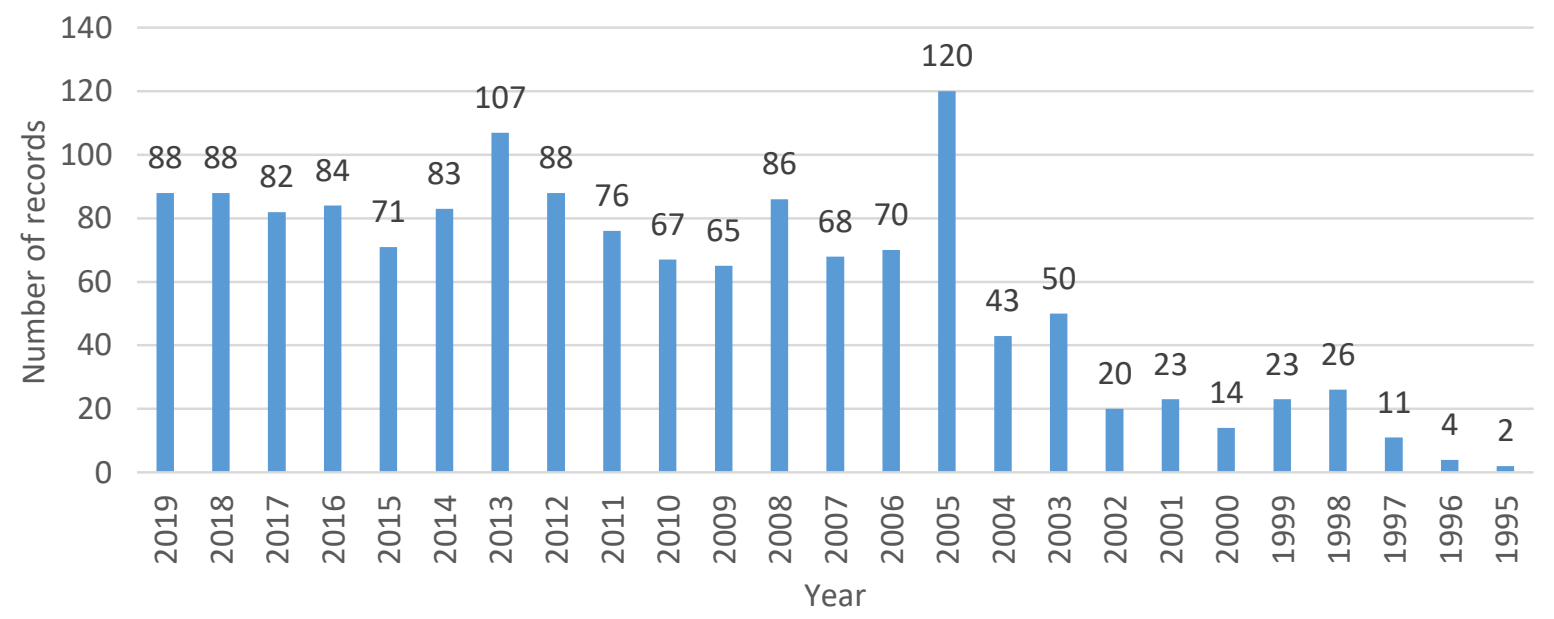

Figure 1. Number of publications with the term "Earnings Management" in Social Science Research Network

years. A deeper analysis reveals the number of publications containing the term "Earnings management" selected by countries, authors, or individual scientific fields. The largest number of publications comes from the USA (635), People's Republic of China (406), Taiwan (112), Australia (98), England (89), Spain (58), Italy (43), and France (36). There are also 10 publications from Poland, two from Slovakia, and one from Hungary. There are no publications from the Czech Republic. Most often, the term "Earnings Management" is the subject of articles in the field of Business Finance, Economics, Management, Business, Operations Research Management Science, Public Administration, or Social Sciences Interdisciplinary, Computer Science Information Systems, Education Educational Research, Ethics, etc. It can be stated that earnings management is a multidisciplinary issue.
Hidden relationships between issues, authors, or disciplines, can be defined based on the science maps. Science maps have been used since the 1970s. Science maps can be defined as representations of scientific fields or organizations in which the elements of the map are associated with topics or themes (Noyons, 2001). The elements in the map can be publications, institutes, authors, instruments, scientific topics, etc. It represents relations among the elements. There are various software for creating science maps. VOSviewer version 1.6.14, released on the $27^{\text {th }}$ of January, 2020 was used.

Figures 3 and 4 are keyword science maps for "Earnings Management" publications. Figure 3 shows data from 1900 to 2000, and Figure 4 shows data from 2001 to 2019.

Source: Authors.

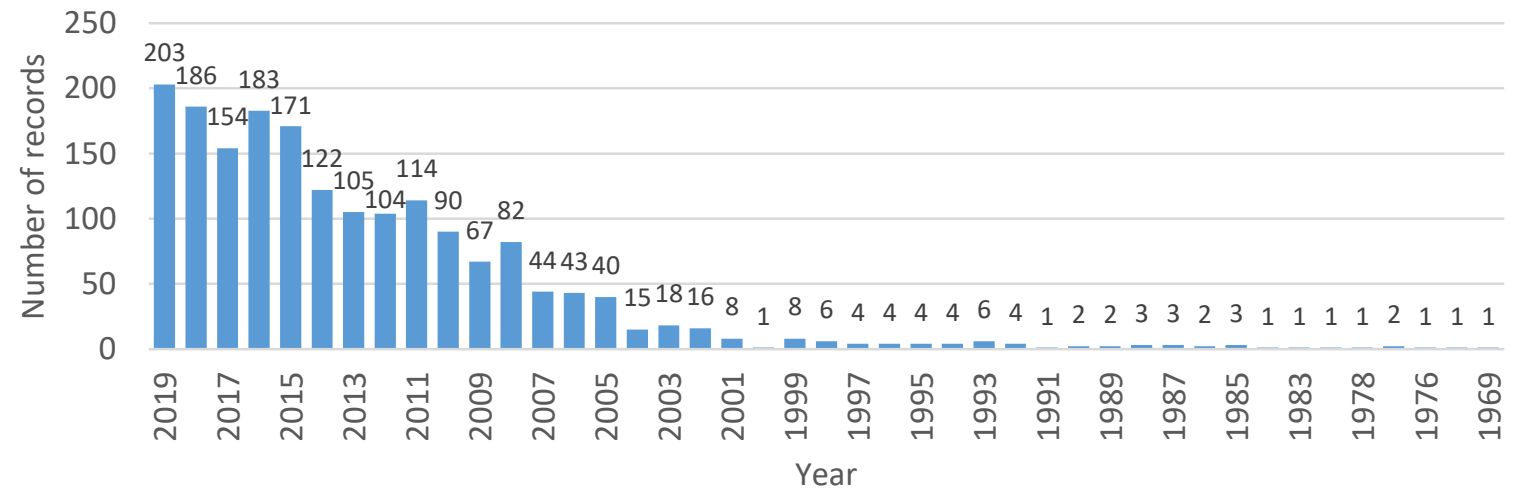

Figure 2. Number of publications with the term "Earnings Management" in Web of Science 
Source: Authors.

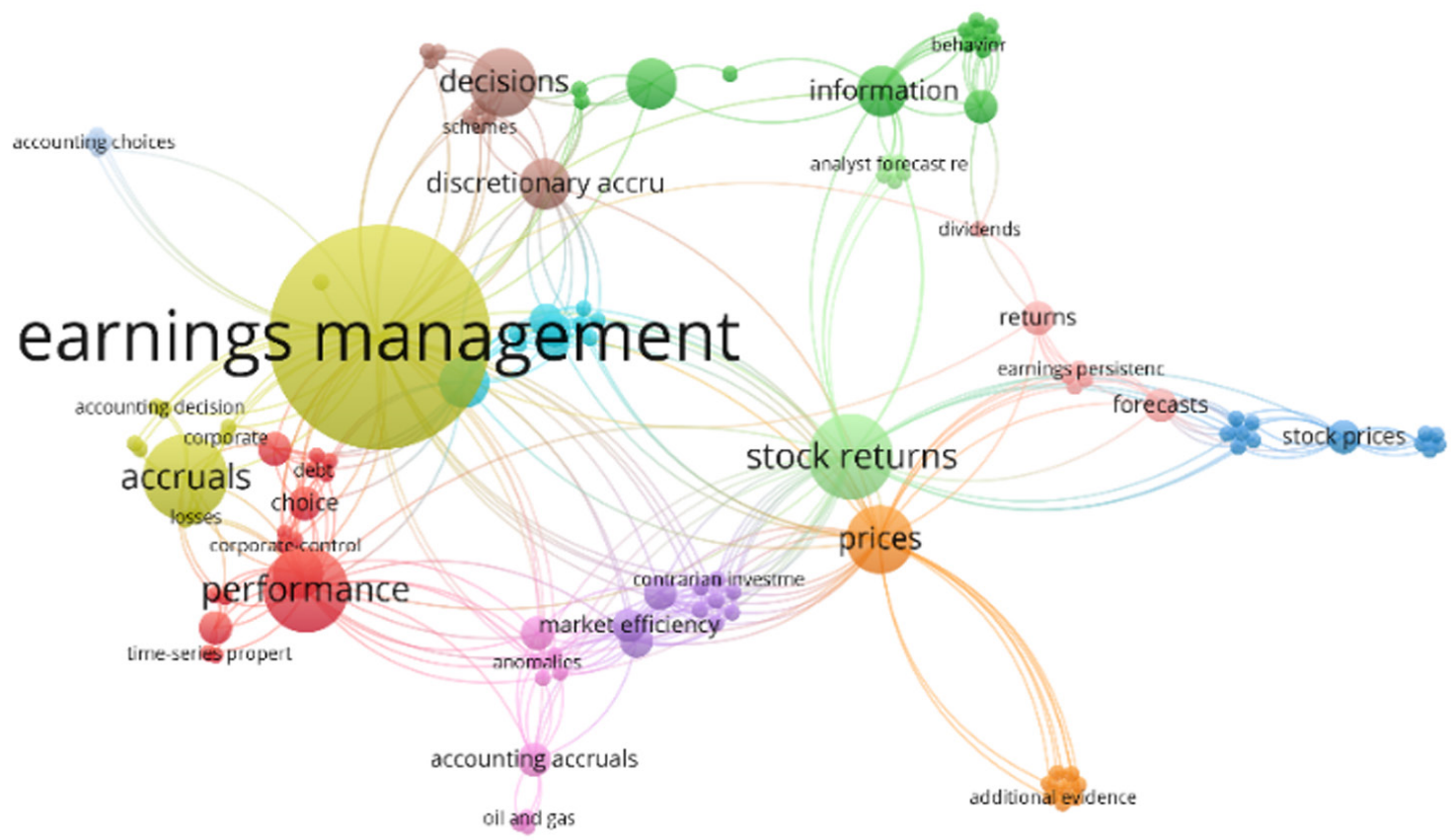

Figure 3. Keyword science maps for Earnings Management, 1900-2000

It was mentioned above that initial studies were focused on earnings management and capital markets. A keyword science map for Earnings Management publications from 1900 to 2000 shows that publications dealing with earnings management also contain keywords such as ac- cruals, performance, stock returns, market efficiency, stock prices, dividends, decisions, information, etc. The size of the circle represents the weight. The larger it is, the higher weight the keyword has. The color of the circles determines the cluster to which the keyword belongs. Lines repre-

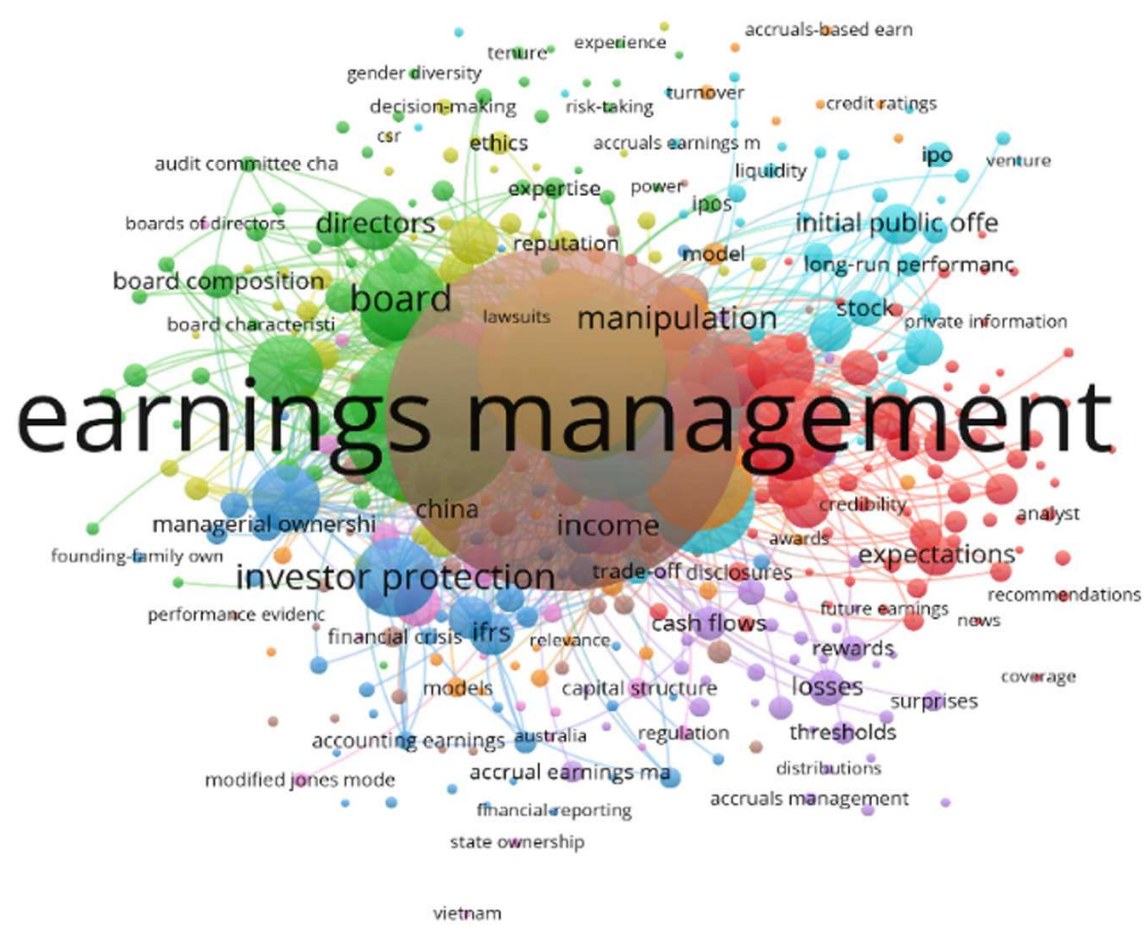

Source: Authors.

Figure 4. Keyword science maps for Earnings Management, 2001-2019 


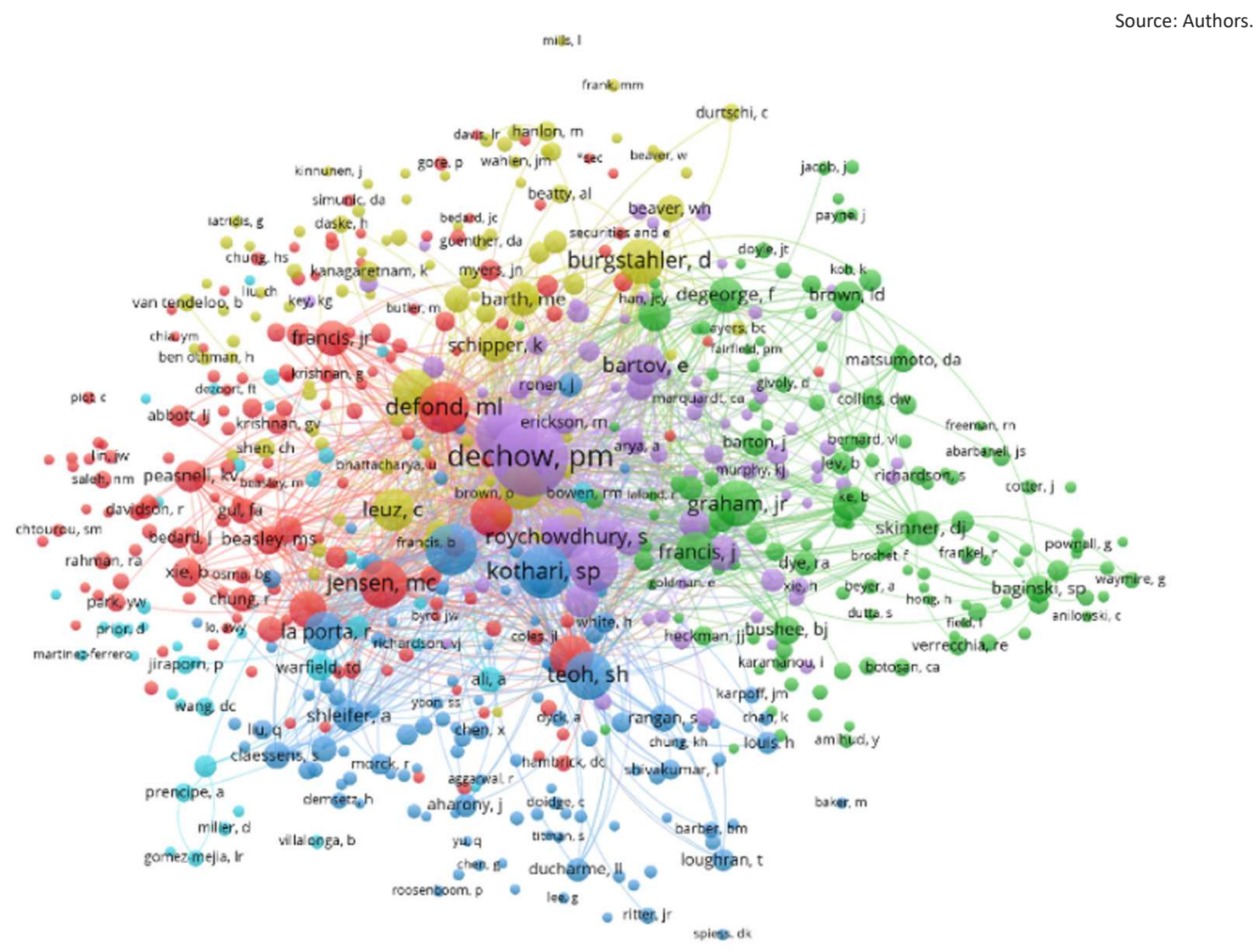

Figure 5. Co-citation analysis - cited authors from 1900 to 2019

sent the connection between keywords. The closer the keywords are, the stronger their connection. Later studies were also focused on the impact of earnings management on the non-capital market. A keyword science map for Earnings Management publications from 2001 to 2019 shows that publications dealing with earnings management also contain keywords such as investor protection, income, stock, manipulation, private information, managerial ownership, cash flow, etc.

Figure 5 represents co-citation analysis - cited authors from 1900 to 2019. The relatedness of authors is determined based on the number of times they are cited together.

Figure 5 shows that the most cited authors dealing with the Earnings Management issue are Dechow, Roychowdhury, Defond, Leuz, Jensen, Kothari, Graham, Bartov, Myers, Skinner, Ronnen, Schipper, etc.

Co-authorship analysis was also conducted. The relatedness of authors is determined based on their number of co-author documents. It can be stated that mainly Chinese authors cooperate in this field of study.

Figure 6 represents a science map of countries with the highest number of cited publications with the term "Earnings Management" from 1900 to 2019.

The highest number of cited publications with the term "Earnings Management" from 1900 to 2019 can be seen in the USA, Australia, Taiwan, Italy, etc.

The last part of the bibliometric analysis is a science map of sources with the highest number of publications with the term "Earnings Management" from 1900 to 2019 (Figure 7).

\section{DATA, METHODOLOGY AND HYPOTHESES}

This section describes data, methods, and hypothesis development. Data for research were obtained from the Amadeus database providing 


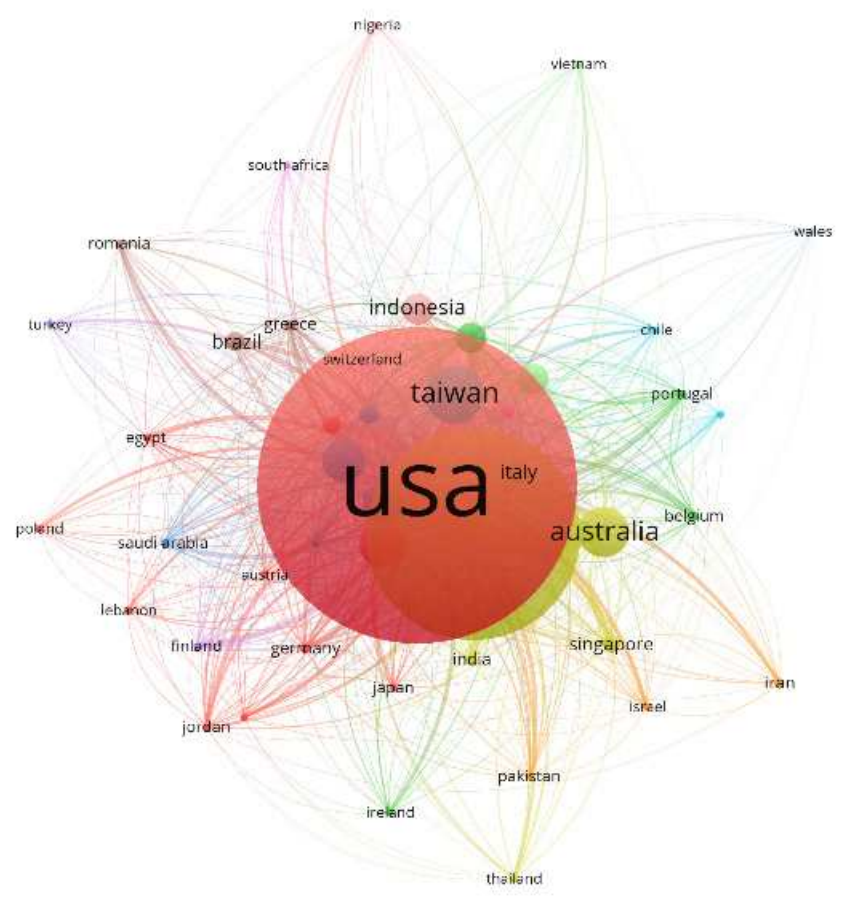

Source: Authors.

Figure 6. A science map of countries with the highest number of cited publications with the term "Earnings Management" from 1900 to 2019

Source: Authors.

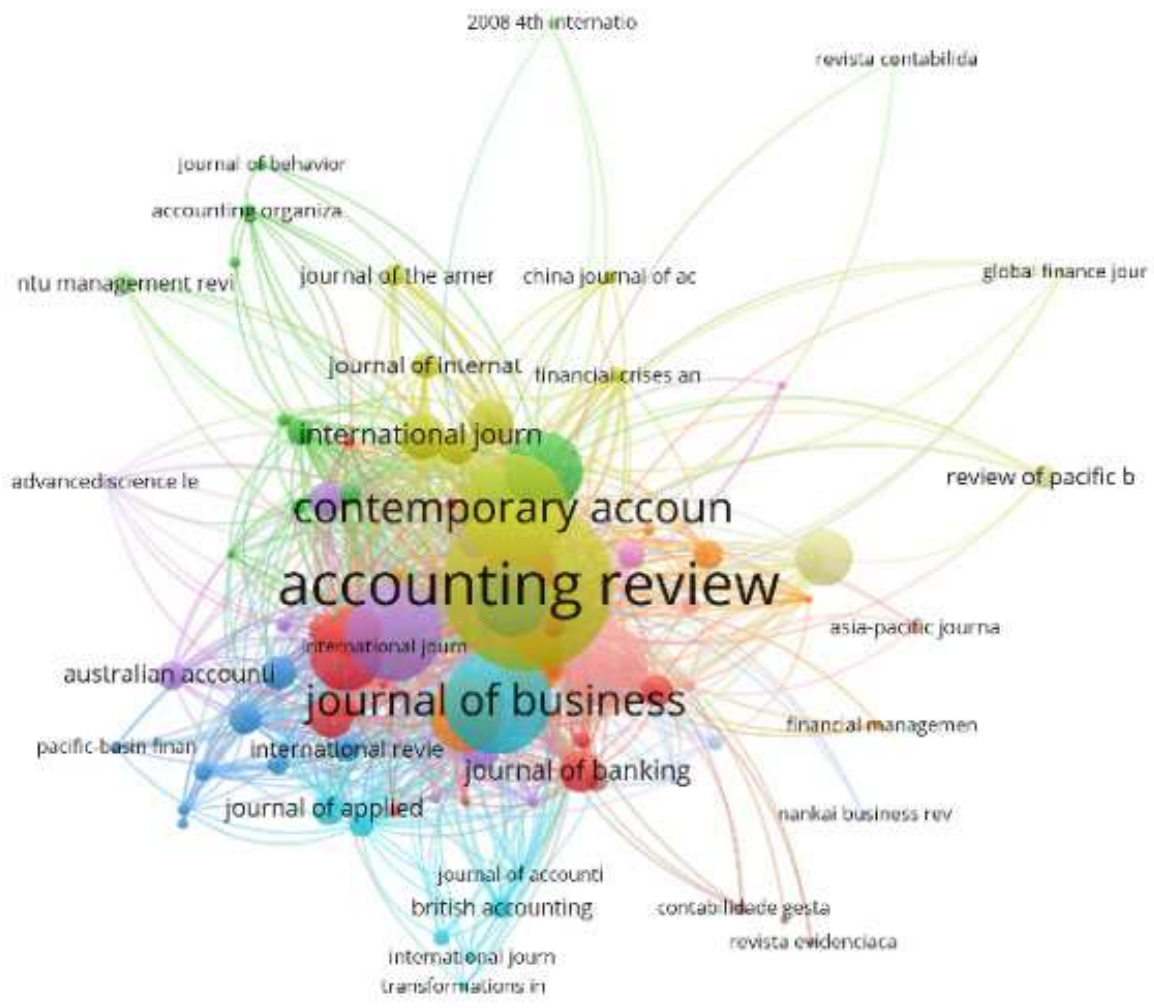

Figure 7. A science map of sources with the highest number of publications with the term "Earnings Management" from 1900 to 2019 
standardized annual accounts (consolidated and unconsolidated), ownership data, sectoral activities, and financial ratios. Obtained data cover financial statements of Czech, Slovak, Polish, and Hungarian entities for 2018. The dataset consists of 1,000 companies, that is 250 companies from each country. IQR (interquartile range) method of outlier detection was used in the sample preparation. Several methods for outlier detection are known. IQR method was developed by John Turkey. Borders were set by Turkey as below.

$$
I Q R=Q_{3}-Q_{1}
$$

where $I Q R$ is the interquartile range, $Q_{1}$ is the first (upper) quartile, and $Q_{3}$ is the third (lower) quartile.

Outliers are defined as $Q_{1}-1.5(I Q R)$ or above $Q_{3}+1.5(I Q R)$ (Al Sayed, Isa, \& Kun, 2018).

Table 1 shows that there are several groups of methods for detecting EM. Mathematical modeling of total discretionary accruals using time series data, specifically the modified Jones model, was used to determine earnings management practices. Based on some studies, the modified Jones model provides the most powerful determination of EM initiatives (Dechow et al., 1995). So-called discretionary accruals (proxy, abnormal accruals) are defined using the modified Jones model. Abnormal accruals are evidence of involved EM practices in firms. The greater the value of abnormal accruals, the lower the quality of the reported economic results. Based on the modified Jones model, discretionary accruals are calculated using the following formulas:

$$
\begin{aligned}
& \frac{T A_{i t}}{A_{i t-1}}=\alpha_{0} \frac{1}{A_{i t-1}}+ \\
& +\alpha_{1} \frac{\Delta R E V_{i t}-\Delta R E C_{i t}}{A_{i t-1}}+\alpha_{2} \frac{P P E_{i t}}{A_{i t-1}}+\varepsilon_{i t}, \\
& T A=N D A+D A,
\end{aligned}
$$
$A_{i t-1}$ is the sum of assets in year $t-1, \triangle R E V$, is the change in revenues between years $t$ and $t-1, \triangle R E C_{i t}$ is the change in receivables between years $t$ and $t-1, P P E_{i t}$ is the sum of the
$H_{1}$ : The distributions of both sets are different (i.e., companies manipulate economic results).

If the calculated $p$-value is less than the selected significance level $\alpha=0.05$, the null hypothesis is rejected and hypothesis $H_{1}$ is accepted.

property, plant and equipment in year $t, \varepsilon_{i t}$ is a statistical error, NDA means non-discretionary accruals, and $D A$ denotes discretionary accruals.

Basically, two methods are known for calculating total accruals:

- the balance sheet approach, and

- the statement of cash flows approach (Hoglund, 2012).

According to the balance sheet approach, total accruals are determined as:

$$
\begin{aligned}
& T A=\Delta C A-\Delta C L- \\
& -\Delta C a s h+\Delta S T D-D e p,
\end{aligned}
$$

where $T A$ is the sum of total accruals, $\triangle C A$ is the change in current assets, $\triangle C L$ is the change in current liabilities, $\triangle C a s h$ is the change in cash and cash equivalents, $\triangle S T D$ is the change in the current maturities of long-term debt and other short-term debt included in current liabilities, and Dep denotes depreciation and amortization expenses.

To verify the existence of earnings management practices, the fictitious file within which the values of discretionary accruals equal zero was set. It means that EM practices are not expected. It allows to find out whether the level of discretionary accruals of a fictitious file is significantly different from the level of discretionary accruals of the analyzed set of V4 companies. The Mann-Whitney nonparametric test was used.

$H_{0}$ : Both sets follow the same distribution (i.e., companies do not manipulate economic results).

The aim of this paper is to identify EM practices and to determine a statistically significant re- 
lationship between EM practices and firm size, country, and business sector. These hypotheses were set as follows:

There is a statistically significant relationship between EM practices and firm size.

There is a statistically significant relationship between EM practices and a country.

There is a statistically significant relationship between EM practices and a business sector.

The one-way ANOVA test was used to verify the hypotheses. If the calculated $p$-value is less than the selected significance level $\alpha=0.05$, the null hypothesis is rejected and hypothesis $H_{1}$ is accepted.

All calculations were performed using statistical analysis software in Excel XLSTAT and are presented in the next part of the contribution.

\section{EMPIRICAL RESULTS AND DISCUSSION}

According to Hoglund's balance sheet approach, the sum of total accruals was calculated, as well as variables for the modified Jones model. Table 3 shows the results of the variables calculation for five selected companies. It is not allowed to name the company, so the general designation in the form of country serial number is used.

Some of the calculated values show deviation from the other. These values are called outliers. Their use in further calculations could falsify the results. IQR (interquartile range) method of outlier detection was used in sample preparation as was mentioned in the methodology part of this study.

In the next steps, the modified Jones model was used to estimate discretionary accruals. Within different studies, several criteria are used to estimate the explanatory power of the model in the EM initiatives calculation. Table 4 represents these criteria, their values, and authors of the studies who used these criteria to describe the explanatory power.

Table 5 shows the explanatory power of the used model within countries. The countries are ranked from those in which the model used achieves the highest explanatory power to those in which the explanatory power of the model is the lowest according to selected criteria.

Table 3. Results of the variables calculation for five selected companies

Source: Authors.

\begin{tabular}{|c|c|c|c|c|c|c|c|}
\hline \multirow{2}{*}{$\begin{array}{c}\text { Selected } \\
\text { Companies }\end{array}$} & \multicolumn{6}{|c|}{ Variables } & \multirow{2}{*}{$\frac{P P E_{i t}}{A_{i t-1}}$} \\
\hline & Country & Sector & Size* & $\frac{T A_{i t}}{T A_{i t-1}}$ & $\frac{1}{A_{i t-1}}$ & $\frac{\Delta R E V_{i t}-\Delta R E C_{i t}}{A_{i t-1}}$ & \\
\hline CZ_25 & Czech Republic & Services & $1.20 \mathrm{E}-05$ & $-8.06 \mathrm{E}-02$ & $1.29 \mathrm{E}-05$ & $-3.44 \mathrm{E}-01$ & 2.05E-01 \\
\hline SVK_02 & Slovakia & Construction & $2.82 \mathrm{E}-05$ & $-3.59 \mathrm{E}-02$ & $1.09 \mathrm{E}-05$ & 5.07E-01 & 2.20E-01 \\
\hline PL_78 & Poland & Retail & $1.97 \mathrm{E}-05$ & $1.56 \mathrm{E}-01$ & $1.58 \mathrm{E}-05$ & $2.63 \mathrm{E}-01$ & 2.13E-02 \\
\hline HU_205 & Hungary & Services & $9.65 \mathrm{E}-06$ & $-1.25 \mathrm{E}-01$ & $9.51 \mathrm{E}-06$ & $1.41 \mathrm{E}-01$ & 2.13E-01 \\
\hline CZ_69 & Czech Republic & Other & $9.18 \mathrm{E}-06$ & $-1.91 \mathrm{E}-02$ & $2.02 \mathrm{E}-05$ & 7.60E-01 & $3.24 \mathrm{E}-02$ \\
\hline
\end{tabular}

Note: * Discretionary accruals are too small compared to the value of the total assets. The natural logarithm of total assets is recommended to use to describe firm size. 
Table 4. Criteria for an explanatory power measurement of the model in calculating EM initiatives

Source: Authors.

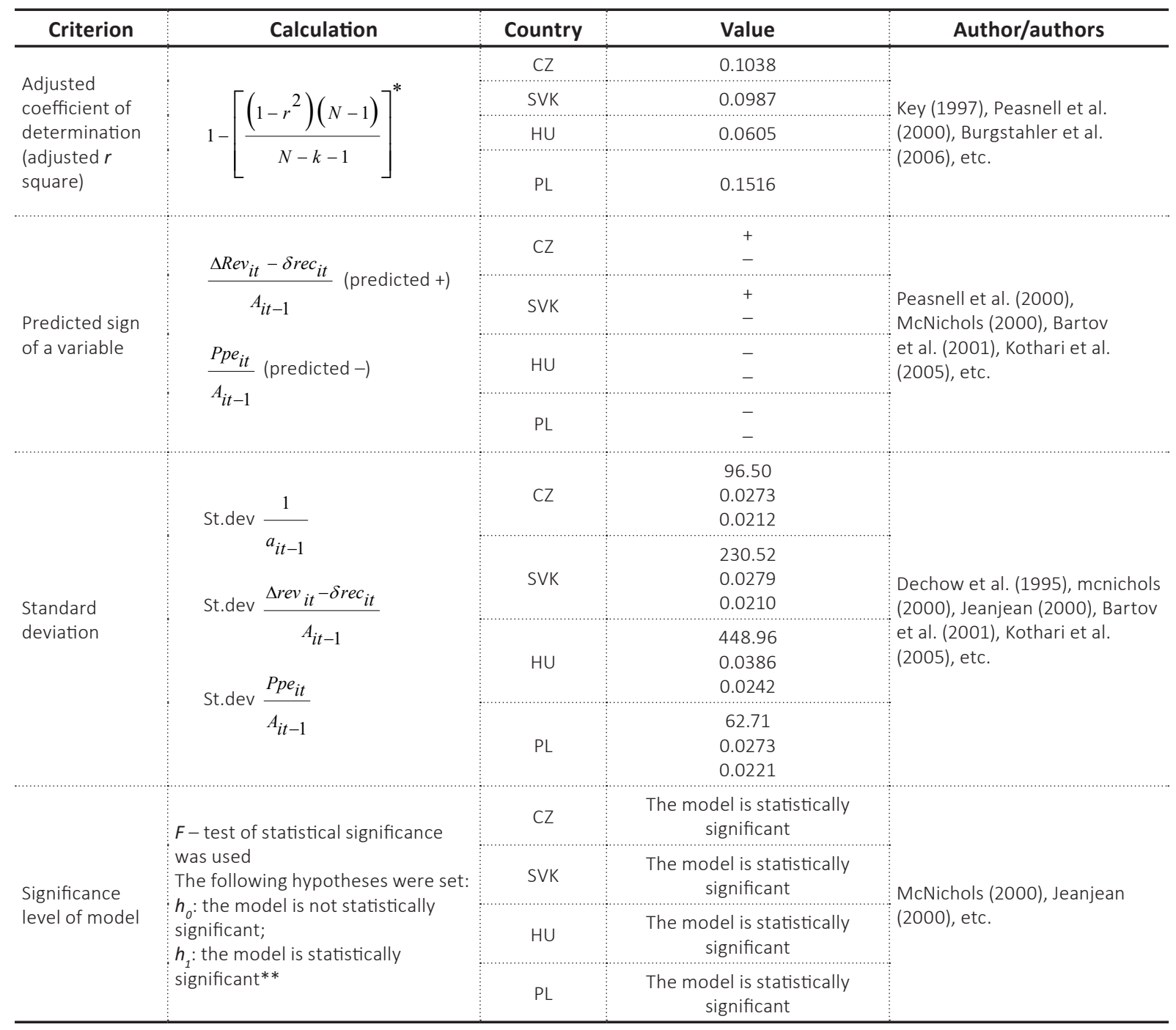

Note: ${ }^{*} R^{2}$ is the coefficient of determination, is the number of elements in the sample, is the number of independent variables. ${ }^{* *}$ If the calculated $p$-value is less than the selected significance level $\alpha=0.05$, the null hypothesis is rejected and hypothesis $\mathrm{H}_{1}$ is accepted. All calculations were performed using statistical analysis software in Excel XLSTAT and are presented in the next part of the paper.

Table 5. Explanatory power of the model used within countries

\begin{tabular}{|c|c|}
\hline Criterion & Country \\
\hline \multirow{4}{*}{ Adjusted coefficient of determination (Adjusted $R$ Square) } & $\mathrm{PL}$ \\
\hline & $\mathrm{CZ}$ \\
\hline & SVK \\
\hline & HU \\
\hline \multirow{2}{*}{ Predicted sign of A variable } & CZ/SVK \\
\hline & $\mathrm{HU} / \mathrm{PL}$ \\
\hline \multirow{4}{*}{ Standard deviation } & $\mathrm{PL}$ \\
\hline & $C Z$ \\
\hline & SVK \\
\hline & HU \\
\hline Model significance level & $\mathrm{CZ} / \mathrm{SKV} / \mathrm{PL} / \mathrm{HU}$ \\
\hline
\end{tabular}


Table 6. Hypothesis testing results

Source: Authors.

\begin{tabular}{c|c}
\hline Country & Results \\
\hline CZ & There is a statistically significant relationship between EM practices and firm size. \\
& There is no statistically significant relationship between EM practices and a country. \\
There is a statistically significant relationship between EM practices and a business sector. & There is a statistically significant relationship between EM practices and firm size. \\
SVK & There is no statistically significant relationship between EM practices and a country. \\
& There is a statistically significant relationship between EM practices and a business sector. \\
& There is no statistically significant relationship between EM practices and firm size. \\
& There is no statistically significant relationship between EM practices and a country. \\
HU & There is no statistically significant relationship between EM practices and a business sector. \\
& There is no statistically significant relationship between EM practices and firm size. \\
There is no statistically significant relationship between EM practices and a country. & The \\
There is a statistically significant relationship between EM practices and a business sector.
\end{tabular}

Note: Significance level $\alpha=0.05$ was used within testing all hypotheses.

As was mentioned above, the Mann-Whitney nonparametric test was used. Within the selected countries, the null hypotheses are rejected and hypotheses $H_{1}$ are accepted - Companies manipulate economic results.

\subsection{Testing hypotheses}

Subsequently, the study is focused on testing the set hypotheses.

There is a statistically significant relationship between EM practices and firm size.
There is a statistically significant relationship between EM practices and a country.

There is a statistically significant relationship between EM practices and a business sector.

One-way ANOVA test was used to verify the hypotheses. If the calculated $p$-value is less than the selected significance level $\alpha=0.05$, null hypothesis is rejected and hypothesis $H_{1}$ is accepted.

All calculations were performed using statistical analysis software in Excel XLSTAT, and results are presented in Table 6.

\section{CONCLUSION}

Interest in the EM problem is proved by the conducted bibliometric analysis. Since 2000, the number of published studies on various aspects of EM has increased significantly. The aim of the paper was to identify EM practices and to determine a statistically significant relationship between EM practices and firm size, country, or business sector. The study was carried out in the economic conditions of the Visegrad Four countries. The modified Jones model was used to verify the existence of earnings management practices in the V4 countries. The results show that there are EM practices in the V4 countries. Also, the explanatory power of the model used was calculated. The modified Jones model is a worldwide model used in EM measurements. It can be seen that the highest explanatory power is in Poland, the lowest explanatory power of this model was observed in Hungary. The study was focused on testing set hypothesis. A statistically significant relationship between EM practices and a country was not proved. As mentioned above, many studies were carried out abroad. It can be seen that the EM issue is published worldwide in many journals and is an important topic at many conferences. There are not many studies focused on the V4 countries. Based on the results of the Jones modified model, the existence of EM initiatives in the V4 countries was proved. By confirming the hypothesis, it can be stated that EM initiatives are used in all the $\mathrm{V} 4$ countries. The results of research in this area mainly reflect the situation abroad. Given the above, the EM issue can be considered as current, and it is necessary to deal with it not only 
abroad, but also within the V4 countries. The results of such studies will better reflect the specifics and economies of these countries. A statistically significant relationship between EM practices and firm size in the Czech Republic and Slovak Republic was proved. There are various ways to calculate EM initiatives. Based on some research, the modified Jones model provides the most powerful definition of EM initiatives. It is a variation of the original Jones model proposed by Dechow et al. in 1995. However, neither model takes company size into account in the calculations. In some countries, it has been shown that there is a statistically significant relationship between business size and EM initiatives. The next study will focus on how the explanatory power of a given model is affected in samples of companies of different sizes. A statistically significant relationship between EM practices and a business sector in the Czech Republic, Slovak Republic, and Poland was proved. Based on proven hypotheses, companies from different industries should be taken into account when examining the explanatory power of models.

Further research will focus on finding the explanatory power of other models in the study of EM, as well as identifying other factors influencing EM initiatives.

\section{AUTHOR CONTRIBUTIONS}

Conceptualization: Anna Siekelova, Katarina Valaskova, Veronika Machova.

Data curation: Katarina Valaskova, Veronika Machova.

Formal analysis: Anna Siekelova.

Funding acquisition: Anna Siekelova, Katarina Valaskova.

Investigation: Anna Siekelova, Katarina Valaskova.

Methodology: Anna Siekelova, Katarina Valaskova.

Project administration: Katarina Valaskova.

Resources: Katarina Valaskova.

Software: Anna Siekelova.

Supervision: Anna Siekelova.

Validation: Anna Siekelova.

Visualization: Anna Siekelova.

Writing - original draft: Anna Siekelova, Katarina Valaskova, Veronika Machova.

Writing - review \& editing: Anna Siekelova, Katarina Valaskova, Veronika Machova.

\section{ACKNOWLEDGMENT}

This paper was financially supported by the Slovak Research and Development Agency - Grant No. APVV-17-0546 Variant Comprehensive Model of Earnings Management in Conditions of The Slovak Republic as an Essential Instrument of Market Uncertainty Reduction.

\section{REFERENCES}

1. Al Sayed, A. R. M., Isa, Z., \& Kun, S. S. (2018). Outliers Detection Methods in Panel Data Regression: An Application to Environment Science. International Journal of Ecological Economics \& Statistics, 39(1), 73-86. Retrieved from http:// www.ceser.in/ceserp/index.php/ ijees/article/view/5426

2. Asghar, A., Sajjad, S., Shahzad, A., \& Matemilola, B. T. (2020). Role of discretionary earning management in corporate governance-value and corporate governance-risk relationships. Corporate Governance - The International Journal of Business in Society, 27(2), 668-701. https://doi. org/10.1108/CG-11-2019-0347

3. Assenso-Okofo, O., Ali, J., \& Ahmed, K. (2020). The effects of global financial crisis on the relationship between CEO compensation and earnings management. International Journal of Account- ing and Information Management, 25(2), 389-408. https://doi. org/10.1108/IJAIM-08-2019-0101

4. Barber, R., \& Hollie, D. (2020). Competition's impact on research and development real activities earnings management. Managerial Finance. https://doi.org/10.1108/ MF-04-2019-0163

5. Davidson, S. and collective. (2005). Accounting: The Language of Busi- 
ness. Arizona: Thomas Horton and Daughters.

6. Dechow, P. et al. (1995). Detecting Earnings Management. The Accounting Review, 70(2), 193-225. Retrieved from https://www.jstor. org/stable/248303?seq=1

7. Durana, P., Kral, P., Stehel, V., Lazaroiu, G., \& Sroka, W. (2019). Quality Culture of Manufacturing Enterprises: A Possible Way to Adaptation to Industry 4.0. Social Science, 8(4), 1-25. Retrieved from https://ideas.repec.org/a/gam/jscscx/v8y2019i4p124-d224410.html

8. Durica, M., Podhorska, I., \& Durana, P. (2019). Business failure prediction using cart-based model: A case of Slovak companies. Ekonomicko-Manazerske Spektrum, 13(1), 51-61. Retrieved from https://www.researchgate. net/publication/334124646_Business_failure_prediction_using_cart-based_model_A_case_ of_Slovak_companies

9. Hoglund, H. (2012). Detecting earnings management with neural networks. Expert Systems with Applications, 39(10), 95649570. https://doi.org/10.1016/j. eswa.2012.02.096

10. Hudakova, M., Masar, M., Luskova, M., \& Patak, M. R. (2018). The Dependence of Perceived Business Risks on the Size of SMEs. Journal of Competitiveness, 10(4), 54-69. https://doi. org/10.7441/joc.2018.04.04

11. Khanh, M. T. H., \& Thu, P. A. (2019). The effect of financial leverage on real and accrual-based earnings management on Vietnamese firms. Economics and Sociology, 12(4), 299-312. Retrieved from https://www.researchgate. net/publication/338591833_The_ effect_of_financial_leverage_on_ real_and_accrual-based_earnings_management_in_Vietnamese_firms

12. Kim, J. H., Lee, S. H., \& Yoo, Y. K. (2020). Real earnings management and the cost of debt capital: international evidence. AsiaPacific Journal of Accounting and Economic, 27(2), 151-172. https:// doi.org/10.1080/16081625.2018.1 518148
13. Kljucnikov, A., Belas, J., \& Smrcka, L. (2016). Risk-taking and Aggressiveness as the Significant Part of the Entrepreneurial Orientation of SMEs: Case of the Czech Republic. Polish Journal of Management Studies, 14(1), 129-139.

14. Kovacova, M., Kliestik, T., Valaskova, K., Durana, P., \& Juhaszova, Z. (2019). Systematic review of variables applied in bankruptcy prediction models of Visegrad group countries. Oeconomia Copernicana, 10(4), 743-772. Retrieved from https://ideas. repec.org/a/pes/ieroec/v10y2019i4p743-772.html

15. Mckee, T. E. (2005). Earnings Management: An Executive Perspective. Indiana: Thomson.

16. Mulford, Ch. W., \& Comiskey, E. E. (2005). The Financial Numbers Game: Detecting Creative Accounting Practices. UK: Wiley.

17. Noyons, E. (2001). Bibliometric mapping of science in a science policy context. Scientometrics, 50, 83-98. Retrieved from https://link.springer.com/ article/10.1023/A:1005694202977

18. Podhorska, I., Gajanova, L., Kliestikova, J., \& Popescu, G. H. (2019). Analysis of internally generated goodwill indicators: A case study of the Slovak Republic. Organizacija, 52(4), 271-285. Retrieved from https://www.researchgate. net/publication/338469321_Analysis_of_Internally_Generated_ Goodwill_Indicators_A_Case_ Study_of_the_Slovak_Republic

19. Premti, A., \& Smith, G. (2020). Earnings management in the preIPO process: Biases and predictors. Research in International Business And Finance, 52(UNSP 101120). https://doi.org/10.1016/j. ribaf.2019.101120

20. Ronen, J., \& Yaari, V. (2008). Earnings Management. US: Springer.

21. Roychowdhury, S. (2006). Earnings management through real activities manipulation. Journal of Accounting and Economics, 42(3), 335-370. https://doi.org/10.1016/j. jacceco.2006.01.002

22. Sadaf, R., Olah, J., Popp, J., \& Mate, D. (2019). Institutional
Ownership and Simultaneity of Strategic Financial Decisions: An Empirical Analysis in the Case of Pakistan Stock Exchange. E \& $M$ Ekonomie a Management, 22(1), 172-188. Retrieved from https://www.researchgate.net/ publication/331735850_Institutional_ownership_and_simultaneity_of_strategic_financial_decisions_an_empirical_analysis_in_ the_case_of_Pakistan_Stock_Exchange

23. Salehi, M., Shiri, M. M., \& Hossini. S. Z. (2020). The relationship between managerial ability, earnings management and internal control quality on audit fees in Iran. International Journal of Productivity and Performance Management, 69(1), 685-703. https://doi. org/10.1108/IJPPM-07-2018-0261

24. Sankar, M. R., \& Subramanyam, K. R. (2001). Reporting Discretion and Private Information Communication through Earnings. Journal of Accounting Research, 39(2), 365-386. https://doi. org/10.1111/1475-679X.00017

25. Schipper, K. (1989). Commentary on earnings management. Accounting Horizons, 3(4), 91-102. Retrieved from https:// www.semanticscholar.org/paper/ Commentary-on-earnings-management-Schipper/38e22e38be93b acea38681d400abf70f3adb679a

26. Suprianto, E., Rahmawati, R., Setiawan, D., \& Aryani, Y. A. (2019). Controlling generation of family firms and earnings management in Indonesia: The role of accounting experts of audit committees. Journal of International Studies, 12(3), 265-276. Retrieved from https://www.jois.eu/?551,en_controlling-generation-of-familyfirms-and-earnings-managementin-indonesia-the-role-of-accounting-experts-of-audit-committees

27. Udell, M., Stehel, V., Kliestik, T., Kliestikova, J., \& Durana, P. (2019). Towards a Smart Automated Society: Cognitive Technologies, Knowledge Production, and Economic Growth. Economics, Management, and Financial Markets, 14(1), 44-49. Retrieved from https://www. addletonacademicpublishers.com/ 
search-in-emfm/3469-towardsa-smart-automated-society-cognitive-technologies-knowledgeproduction-and-economic-growth

28. Vrbka, J., Nica, E., \& Podhorska, I. (2019). The application of Kohonen networks for identification of leaders in the trade sector in Czechia. Equilibrium - Quar- terly Journal of Economics and Economic Policy, 14(4), 739-761. Retrieved from https://ideas. repec.org/a/pes/ierequ/v14y2019i4p739-761.html

29. Whittle, T., Gregova, E., Podhorska, I., \& Rowland, Z. (2019). Smart Manufacturing Technologies: Data-driven Algorithms in
Production Planning, Sustainable Value Creation, and Operational Performance Improvement. Economics, Management, and Financial Markets, 14(2), 52-57. Retrieved from https://go.gale. $\mathrm{com} / \mathrm{ps} /$ anonymous? id=GALE $\% 7$ CA594318015\&sid=googleSchola $\mathrm{r} \& \mathrm{v}=2.1$ \&it $=\mathrm{r} \&$ linkaccess $=\mathrm{abs} \& \mathrm{is}$ $\mathrm{sn}=18423191 \& \mathrm{p}=\mathrm{AONE} \& \mathrm{sw}=\mathrm{w}$ 